\title{
Systematic Review of The Studies in Turkey During Covid-19 Curfew
}

Zihniye Okray, European University of Lefke, Lefke, Northern Cyprus TR-10 Mersin, Turkey, zokray@eul.edu.tr, ORCID: 0000-0002-9117-4991

\begin{abstract}
Covid 19, Corona Virus pandemic has caught every segment of society unprepared in our country as well as all over the world. In this process, students and teachers have had to switch from faceto-face education to the online education within a short period of time such as a few weeks. This training and measurement evaluation process, which is carried out on different digital platforms, has brought with it different challenges for both students and teachers.

Although there are studies on distance education effectiveness and success, studies in the first, middle, high school and university areas of distance education are limited during the pandemic process. There are no studies related to distance education during pandemic periods that have occurred before in the world in the study of the field. The fact that other important pandemics affecting the world occur at different ages and technology is almost nonexistent compared to now at that time, which can be considered as the main factor that can explain this situation.

In this systematic review articles that are published in 2020, which are related with Covid 19 pandemics evaluated after the quarantine process had begun. The aim of this study is to systematically evaluate the problems, solution proposals and development studies expressed by teachers and students who are in mainly continue their education upon EBA regarding the pandemic process.

As a result, it was concluded that although e-learning have some advantages and disadvantages during this extraordinary period of time related with the unstoppable spread of coronavirus throughout the world online education seems to be the best way to continue education.
\end{abstract}

Keywords: Covid-19, school closure, e-learning, online education, Turkey.

Received: $15.11 .2020 \quad$ Accepted: 09.12.2020

Published: 14.01 .2021

\section{INTRODUCTION}

The world has changed dramatically since the start of the COVID-19 pandemic and this has included education at all levels. Online teaching and learning is an unprecedented experience for most teachers and students; although they have limited experience with this, and continuing the e-learning process has become a major challenge for the education community globally. Although e-learning has been spread worldwide after the development in United States in 1998. Online education is one of the most important and effective educational method nowadays. Online education or e-learning was used as a supplement to regular school education before the Covid-19 pandemics worldwide. In the normalized education and teaching practice, more students go to schools to participate in traditional classroom teaching, and large-scale online education lacks practical application scenarios. (Zhou, Li, Wu and Zhou, 2020).

Online learning is described as learning experiences in synchronous or asynchronous environments using different devices such as mobile phones, laptops, tablets and etc. with internet access (Singh and Thurman, 2019). Littlefield (2018) defined synchronous online learning as a more structured learning strategy where lessons are scheduled at specific times and in live virtual classroom environments where they can receive simultaneous feedback. On the other hand, asynchronous online learning cannot get instant feedback and message. Additionally, the learning content is not provided in live classes, but rather on different learning management systems or forums (Littlefield, 2018).

School closures in many countries worldwide during the spread of Covid-19 as a precaution over a 400 million of learners being excluded from face-to-face classroom education learning process. According to Huang, Liu, Tlili, Yang, Wang et al.(2020) challenges were reported worldwide during this online education period which can be summarized as; unreliable internet connection due to the overload of thousands of learners online at the same time, thousands of resources published online and instructors can find it difficult to find most suitable teaching context for themselves, instructors and learners do not have digital skills in order to teach and learn online, learners may lack of important learning abilities such as self-regulation, independent study and motivation for online learning and instructors can be stick to 
directions without paying attention to be more interactive, socially and cognitively present during online teaching which may result as un-motivational factor for learners.

\section{ONLINE EDUCATION IN TURKEY during covid-19 curfew}

\section{Switch to Online Education in Turkey}

In this process, schools in Turkey were closed from 16 March 2020 to April 30, 2020 in the first phase, open and distance education at the primary and secondary level within the scope of the applications of $3 \mathrm{TV}$ Channels and Education Information Network (EBA) through the continuation of education (Meb, 2020). With the continued effects of the pandemic, a decision taken on April 29, 2020 will extend the school's closure period until 31 May 2020, the education will be continued with distance education, students will apply their first-term grades for passing classes and will be upper class under any circumstances (Can, 2020).

Due to coronavirus (Covid-19) pandemic, education was suspended in the higher education system on March 12, 2020, and from March 23, 2020, the 2019-2020 academic year is completely open and remote learning system (YÖK, 2020a). For this purpose, the YÖK Courses Platform (Higher Education Institutions Courses) has been made available to all students (YÖK, 2020b). In addition, the Presidency of the Higher Education Council (YÖK, 2020c) has taken a decision coronavirus (Covid-19) due to pandemic degree, undergraduate and graduate level education students can freeze their registration during the spring semester of the 2019-2020 academic year; thesis defense and proficiency examinations can be done with digital facilities such as video conferencing, provided that they are auditable and "recorded". In addition, nearly to all higher education institutions have started to publish online exam instruction principles by preparing to carry out midterm and final exams for graduate and undergraduate programs all online.

\section{Education Information Network (EBA)}

The Project, which is also the Movement to Increase Opportunities and Improve Technology (Fatih) in Turkey, has been an important milestone in the process of fusing education and training processes with technology. Fatih project was done to ensure that our students have the most contemporary education, reach the most up-to-date educational content and that the right to education for each student is provided with justice and the largest project to be implemented in education related to the use of technology. Many schools with Fatih project smart board, tablet computer, document camera, multifunctional printer, internet network infrastructure equipped, teachers were given in-service training about Fatih project and EBA website was created to provide e-comers and students and teachers to benefit from these content (MEB, 2017).

The EBA website was first released in 2012 with the EBA test version. The second version of the EBA was released in September 2015 with its new design, and until December 1, 2016, this design of EBA was used and the third version was released on December 1, 2016 (Bahçeci \& Efe, 2018, Pala, Arslan \& Özdinç, 2017). EBA the website is an online social education platform that provides free use to everyone, has passed and reliable, and includes e content that is constantly e-developed with new shares of students and teachers (Education Information Network [EBA], 2017). The EBA includes sources of audio, writing, pictures and videos. The ability to provide digital space and upload files, courses, contest syllabus, make announcements and share users in accordance with different class levels is a few of the features that enrich the EBA system (Bahçeci \& Efe, 2018, Aktay \& Keskin, 2016). On March 20, 2020, three separate television channels were opened for TRT-EBA TV Primary School, Secondary School and High School in order to continue the education of students during Covid-19 pandemics and curfew in Turkey.

\section{METHODS}

In this systematic review articles that are published in 2020 and which are related with Covid 19 pandemics evaluated after the quarantine process had begun. The aim of this study is to systematically evaluate the problems, solution proposals and development studies expressed by teachers and students who are in mainly continue their education upon EBA regarding the pandemic process.

In Turkey TUBITAK offers electronic hosting and editorial process management services for academic journals published in Turkey under the umbrella of ULAKBiM. DergiPark supports national academic journals to gain presence in accordance with standards and increase international visibility. In this systematic review study DergiPark database was screened with keywords 'Covid-19', 'online education', 'e-learning' and 'distance-education'. With those mentioned keywords 35 articles revealed from DergiPark database. From those articles some inclusion and exclusion criteria was adapted which was listed below. 
i-Articles which was published in 2020 but they are dated back to pre-pandemics period was excluded. $(\mathrm{n}=6)$

ii- $\quad$ Editorial letters were excluded $(n=1)$

iii- $\quad$ Review studies was excluded ( $\mathrm{n}=7$ )

iv- $\quad$ Articles related with the higher education were excluded $(n=18)$.

v- Articles which are related with pandemics and EBA learning platform were included in this research $(\mathrm{n}=4)$. (Table 1.)

Screening was revealed in July 2020.

\section{RESULTS}

In this systematic review study Geçgel, Kana and Eren (2020), Çakın and Külekçi Akyavuz (2020) and Kesendere, Sakin and Acar (2020) studied about the determination of teachers' opinions about onlineeducation, students' digital competence skills, problems about online-education process and the methods that teacher used to motivate their students during Covid-19 and curfew period in Turkey. On the other hand, Canlı and Canlı (2020) studied about the students' opinions and thoughts about online education during Covid-19 and curfew period. All of the mentioned studies used semi-structured interview form and gathered the analyzed data online in their researches. Also all of the mentioned studies used qualitative research method with either purposeful sampling or convenience sampling method. The sampling size differs between 7 to 32 participants.

Geçgel, Kana and Eren (2020); research sample was chosen from a government secondary school teachers. Teachers ask to answer the semi-structured interview form in order to get their opinions about the digital competence skills of secondary school students. Different interview forms were used for teachers and school manager. School manager was asked 5 questions to give feed-back about the physical infrastructure and adequacy of the school and teachers were ask 6 questions to give their opinions about teaching programs and textbooks and also 7 questions for their opinions about online-education. Age range of the participants differs between 33 to 49 with a mean age 37,5 and the participants experience years are differing between 5 to 24 years with a mean experience year 13,83. The school manager was 47 years old and had a 5 years' experience in management.

The findings of this research are as follows. It has been emphasized by teachers that although the interactive boards are sufficient in schools, the computers that exist in the school are not suitable for the digital age, that they are inadequate as hardware. Teachers participating in the study said that the school building was not enough to create a technological space, that smart boards disrupted teaching, that they had problems with updating computers and internet connection in schools, and that EBA was restricted by the Ministry of National Education because the internet was restricted. They are not used effectively; they cannot use youtube channels in listening texts due to access barriers.

In the teachers' opinion students are more interested in solving tests because there are exam preparations instead of turning to technological tools for project or research at school. Participants say students rarely use technology to do projects and research, but are not enthusiastic about it.

Teachers, Turkish course work books and EBA's content of the digital environment cannot be provided; students are willing to use digital media, especially the use of EBA; animations for listening texts will increase students' interest and desire, links such as films should be added to events to provide visuality to events, and that short films related to topics in books should be created, especially in lower classes. They stated that Turkish textbooks are bad in terms of technology and there are too many wrong questions in EBA. The content directed by the workbooks cannot be found, there should be puzzles for visual intelligence and digital activities that the student can complete.

According to teachers' opinion students do not write texts prepared in digital environments in accordance with the rule and make a number of technical errors is revealed.

Teachers say that the theme of Science and Technology raises awareness, allows students who are interested in this field to discover, that the texts in this field can remain superficial, and that it prompts students to research technology.

That teachers meet texts found by students as copy-paste, that students cannot write the resources they benefit from, that they often guide students by giving them feedback; they encourage students to read books, tell and interpret the text they read, they are not enough to distinguish the misinformation from the right information, they do not know what to investigate, some students even put site ads in their homework without questioning.

Teacher's in this study also added that The seminars which are held by The National Ministry of Education about online-education and using of EBA and other technology related educational processes is insufficient due to crowd sessions and limited amount of experienced educators who gave these seminars. 
Çakın and Külekçi Akyavuz (2020), studied Teachers' opinions about the problems of education process in Covid-19 and how they motivate their students with 20 primary and secondary school teachers. The sample of the study was formed 12 male and 8 female teachers whose experience differs from 2-19 years with mean experience year of 8,5 years. Teachers are from 10 different branches which are classroom teacher $(n=9)$, guidance teacher $(n=2)$, kindergarten teacher $(n=2)$, physical education teacher $(n=1)$, drama teacher $(n=1)$, mathematics teacher $(n=1)$, English teacher $(n=1)$, special education teacher $(n=1)$, science teacher $(\mathrm{n}=1)$ and Turkish teacher $(\mathrm{n}=1)$.

In this research the problems experienced by the teachers in this process were addressed in 3 categories as communication problems, problems with parents and problems with students' learning. Communication problems category; consists of the codes of as lack of feedback, limited communication, students who cannot be reached, having limited internet, not being face to face and high number of students. Codes created in the category of problems with parents; Lack of support, academic incompetence, not giving feedback, not being able to reach, being indifferent, not having the habit of studying, technological inadequacy, not being willing, parents were expressed themselves as being anxious, getting bored and not reporting their needs. The category of problems related to the education of students codes formed as; not being able to follow up students, not having enough materials at home, not having face-toface education, not being sure of what they learned, not enjoying online lessons, lack of technology, not being able to conduct some activities remotely, incomplete homework, inability to identify individual needs, students' inability to adapt, distractions at home, perception that 'I will pass the class already'. The second problem of the study is to determine the teachers' motivation techniques that they use among online education process. From the obtained data from interviews analyzed and 5 categories have been found: saying good words, doing supportive activities, making the school feel ongoing, doing health studies and encouraging it for the future. Doing supportive activities category was determined as the most preferred motivation method for teachers. This category; consists of having fun activities, appreciating students, telling compensatory training will be done, sending cheerful music, sending emoji's and star, sharing homework as status on WhatsApp, joking with students, having drama studies and virtual museum tours. The category of promoting for the future; consists of the codes saying that schools will be reopened, those who do the homework saying that they will pass the class, and that they will travel when the schools are re- opened. The category of making the school feel continuing; consists of providing interaction among children, giving quick feedback, giving daily homework, telling that the school continues with distance education, telling who sees EBA TV, making and sharing a homework follow-up chart, and helping with access problems they experience. Health studies category; consists of the codes to share posters and brochures, to have sports activities and to remind the importance of a balanced diet. Poster-Brochure sharing has been the most repeated code in this category. The category of saying nice words; consists of the codes to say that he/she misses them and to say what he/she sees in his/her dreams that they having fun in school.

Table 1. Systematic Review Articles' Properties

\begin{tabular}{|l|l|l|l|}
\hline $\begin{array}{l}\text { Authors/ Publication } \\
\text { Year }\end{array}$ & Subject & Method/Material & Population/Sample \\
\hline $\begin{array}{l}\text { Geçgel, Kana and Eren } \\
\text { (2020) }\end{array}$ & $\begin{array}{l}\text { Teachers 'views on } \\
\text { secondary school } \\
\text { students' digital } \\
\text { competence skills }\end{array}$ & $\begin{array}{l}\text { Qualitative research, } \\
\text { purposeful sampling, } \\
\text { case study semi- } \\
\text { structured interview } \\
\text { form }\end{array}$ & $\begin{array}{l}\text { Government Secondary } \\
\text { School, School manager } \\
\text { (n=1), Turkish } \\
\text { Education Teacher } \\
\text { (n=5), ITC Teacher(n=1) }\end{array}$ \\
\hline $\begin{array}{l}\text { Çakın and Külekçi } \\
\text { Akyavuz(2020) }\end{array}$ & $\begin{array}{l}\text { Teachers' opinions about } \\
\text { the problems of education } \\
\text { process in Covid-19 and } \\
\text { how they motivate their } \\
\text { students. }\end{array}$ & $\begin{array}{l}\text { Qualitative research, } \\
\text { convenience sampling } \\
\text { method, } \\
\text { phenomenological } \\
\text { study, semi-structured } \\
\text { interview form. }\end{array}$ & $\begin{array}{l}\text { Government primary } \\
\text { and secondary school } \\
\text { teachers (n=20) }\end{array}$ \\
\hline Canlı and Canlı (2020) & $\begin{array}{l}\text { Investigate the current } \\
\text { thoughts of young } \\
\text { learners of English about } \\
\text { distance education and and } \\
\text { their preferences while } \\
\text { choosing activities to } \\
\text { improve their English }\end{array}$ & $\begin{array}{l}\text { Qualitative research, } \\
\text { purposeful sampling, } \\
\text { interview form }\end{array}$ & $\begin{array}{l}\text { Private and Government } \\
\text { Primary School Students } \\
\text { (n=32) }\end{array}$ \\
\hline
\end{tabular}




\begin{tabular}{|l|l|l|l|}
\hline & $\begin{array}{l}\text { during the curfew due to } \\
\text { COVID- 19. }\end{array}$ & \\
\hline $\begin{array}{l}\text { Kesendere, Sakin and } \\
\text { Acar(2020) }\end{array}$ & $\begin{array}{l}\text { Educators' views on } \\
\text { online education methods } \\
\text { in violin education. }\end{array}$ & $\begin{array}{l}\text { Qualitative research, } \\
\text { purposeful sampling, } \\
\text { semi-structured } \\
\text { interview form }\end{array}$ & $\begin{array}{l}\text { Violin educators } \\
\text { working in different } \\
\text { institutions (n=13) }\end{array}$ \\
\hline
\end{tabular}

Kesendere, Sakin and Acar (2020) studied determination of the educators' opinions on the use of online education methods with educators who are working in different institutions as private institution, government institution, school music department and conservatory. The minimum experience of the educator is at least one year and the maximum year of experience is 15 years and over. The sample of the study form 13 volunteer educators who answer the semi-structured interview form online and via e-mail. The researchers tried to find answers to following questions which can be summarized as: Which technological materials and resources was used, their thoughts about online violin education, in which stage is most appropriate for the student to take online education who play an instrument. Participants' views about the targeted achievement at different levels of instrument education were analyzed with the content analysis method, 11 themes and 80 codes were obtained.

Participants use a wide range of educational materials in training such as applications, websites and technological materials. Both positive and negative thoughts expressed about the use of the online education. Negative thoughts indicated by 5 participants was that it was not useful in beginner phase. Other negative thoughts emphasized by the participants includes correction of errors took more time than usual and it can be only a supportive method. The positive thoughts on the subject, includes the ideas that the online educational methods were more useful in advance levels and at the preparation stage before a live performance like concerts also participants added that it can be also useful when the reach to the educators is not available due to physical barriers. One participant said there should be parental involvement and support especially in young ages.

Educators views were based on the effectiveness of online education were in skills development, course preparation, course repetition, concert preparation, compensatory lessons, supporting with family participation and all of these can be used at any stage according to the answers to the theoretical topics of the participants. Most participants should be supported by face-to-face training themed online/distance learning method performing violin training gains online/with distance education in the first month.

The only study in this review which is done with students belongs to Canlı and Canlı (2020). Canlı and Canlı (2020) investigates the current thoughts of young learners of English about distance education and their preferences while choosing activities to improve their English during the curfew due to COVID19. Data gathered online from 32 private and government school primary school students with a semistructured interview form. The ages of the students range from 7 and 10 year-olds. Recently, 24 of the participants have been attending private primary schools and 8 of them have been attending state primary schools. 22 students are in the first grade, 2 of them are in the second grade, one of them is in the third grade and 7 of them are in the fourth grade.

Results obtained from the rea-search about the online resources and material that young learners of English used was as follows: 20 students claimed that they entered the website of Eba.gov.tr and follow their daily lessons there and they try to struggle the difficulties caused by coronavirus pandemic on the net. 5 of them claimed that Okulistik.com was very helpful for them to spend their leisure time. 4 of them expressed that their parents bought memberships for them from Morpakampus.com to learn English, and 6 students said that they paid for using Mentalup.net and found it quite beneficial and enjoyable. 29 of the participants described that they played online games and downloaded game applications on tablets, pc and their parents' mobile phone day after day. 7 students said that they had some applications to learn English on their tablets. One of the participants who used online resources to learn English during the curfew due to the pandemic.

The second question that asked in the study was about what method of education that students prefer and why. 30 participants claimed that they preferred to learn and continue their education with face to face education instead of distance education.

\section{DISCUSSION AND CONCLUSIONS}

Covid-19 Pandemic has affected the world through curfews and such from late 2019 and still in the ongoing future. Most of the sectors that needs face-to-face interactions like tourism and education are the most affected sectors all over the world. The Covid-19 pandemic started to affect our country in the midst of March 2020 when Turkish Education Ministry and also Higher Council of Education took precautions to 
pause the education system for two weeks and declared that the education of 2019-2020 spring semester will continued as online and with distanced education.

According to Miks and McIlwaine (2020) 1.6 billion children are unable to attend school in person and continue their education and learning processes at home. Most of the countries that are developed or not, started to give education for their children and youth through radio, television and where appropriate online (Miks and Mcllwaine, 2020). Turkey is one of the first countries in the world which starts online education via EBA TV and also via internet. Although EBA TV was podcasting since 2012 with the Covid-19 pandemic and closure of schools it starts to develop more rapidly and quickly to support primary, secondary and high school education via distanced education.

The aim of this study is to gather the information about online and distanced education in Turkey during the Covid-19 Pandemic and curfew period. With this basic aim literature search was done and total 4 articles fall into the interest of this study. All of the studies was done in the first steps of education including primary, secondary and high school education. Geçgel, Kana and Eren (2020), Çakın and Külekçi Akyavuz (2020) and Kesendere, Sakin and Acar (2020) studied about the determination of teachers' opinions about online-education, students' digital competence skills, problems about online-education process and the methods that teacher used to motivate their students during Covid-19 and curfew period in Turkey. On the other hand, Canlı and Canlı (2020) studied about the students' opinions and thoughts about online education during Covid-19 and curfew period.

Geçgel, Kana and Eren (2020) in their research found out that that interactive boards are sufficient in schools due to the FATIH project, but computers are not at a level to meet the needs and are not suitable for the digital age. It was seen that the students grew up in the exam center rather than the project center, so there was a problem in turning to technological tools. $\mathrm{Zhou}, \mathrm{Li}, \mathrm{Wu}$ and $\mathrm{Zhou} \mathrm{(2020)}$ also discussed in their articles that large scale application of online education can cause some problems when they implemented first. Basilaia and Kvavadze (2020) also reported that especially in the first week of switching to the online education have some problems too in their home country. Sharma and Sharma (2020) reported that teachers faced with technical problems and connection problems which are included not friendly with the new technology in other words lack of skills.

Çakın and Külekçi Akyavuz (2020) discovered that problems experienced by the teachers during this period in were addressed in 3 categories as communication problems, problems with parents and problems with students' learning. Communication problems category; consists of the codes of as lack of feedback, limited communication, students who cannot be reached, having limited internet, not being face to face and high number of students. Codes created in the category of problems with parents; Lack of support, academic incompetence, not giving feedback, not being able to reach, being indifferent, not having the habit of studying, technological inadequacy, not being willing, parents were expressed themselves as being anxious, getting bored and not reporting their needs. The category of problems related to the education of students codes formed as; not being able to follow up students, not having enough materials at home, not having face-to-face education, not being sure of what they learned, not enjoying online lessons, lack of technology, not being able to conduct some activities remotely, incomplete homework, inability to identify individual needs, students' inability to adapt, distractions at home, perception that 'I will pass the class already'. Basilaia and Kvavadze (2020) demonstrate that online learning should no longer be advanced and popular to reorganize exams and home assignments to the open book principle. Additional work will be required to prepare a new type of such assignments in all subjects. The problem of note-taking is real, where students stay out of school and new technologies must be taken into account to avoid antiplagiarism and cheating. Sintema (2020) also reported that subjects will be negatively affected in terms of student performance in national exams and teachers expect a decrease in students' performance.

Kesendere, Sakin and Acar (2020) studied determination of the educators' views on the use of online education methods with educators who are working in different institutions as private institution, government institution, school music department and conservatory. Majority of the participants emphasized that the online education method should be used as a supporting teaching method together with face-to-face education. Elhaty, Elhadary, Elgamil and Kılıç (2020) studied the teachers and students' opinions about the effects of online education upon practical classes. Their study shows that teachers (83.3\%) and students (53.4\%) believe that practical skills are affected by the lockdown due to the crisis. There is a little difference in the opinions of students and also of teachers of science and social science related to the size of the issue and how it can be solved. Teachers and students of science are more concerned about the impact of poor practical skills on their future career than social science students. Teachers (55.8\%) and students (40.8\%) prefer live teaching and recording of the practical courses more than other teaching modes.

Canlı and Canlı (2020) investigates the current thoughts of young learners of English about distance education and their preferences while choosing activities to improve their English during the 
curfew due to COVID- 19. Participants of this study claimed that they preferred to learn and continue their education with face to face education instead of distance education. Sreehari (2020) found out that students prefer online learning as they are comfortable with e-learning and they can learn at their own pace, students consider that online classes are not at all engaging; students think that online learning is difficult due to network and bandwidth problems; students favour blended learning approach from now on, and they prefer a blend of $30 \%$ of online and $70 \%$ of face-to face education.

Although e-learning have some advantages and disadvantages during this extraordinary period of time related with the unstoppable spread of coronavirus throughout the world online education seems to be the best way to continue education.

\section{REFERENCES}

Aktay, S., \& Keskin, T. (2016). Eğitim bilişim ağı (EBA) incelemesi. Eğitim Kuram ve Uygulama Araştırmaları Dergisi, 2(3), 27-44.

Bahçeci, F. \& Efe, B. (2018). Lise öğrencilerinin Eğitim Bilişim Ağı (EBA) sitesine yönelik görüşlerinin değerlendirilmesi. Kuramsal Eğitimbilim Dergisi [Journal of Theoretical Educational Science], 11(4), 676-692.

Basilaia, G., \& Kvavadze, D. (2020). Transition to Online Education in Schools during a SARS-CoV-2 Coronavirus (COVID-19) Pandemic in Georgia. Pedagogical Research, 5(4), em0060. https://doi.org/10.29333/pr/7937.

Can, E . (2020). Coronavirüs (Covid-19) pandemisi ve pedagojik yansımaları: Türkiye'de açık ve uzaktan eğitim uygulamaları. Açıköğretim Uygulamaları ve Araştırmaları Dergisi , 6 (2) , 11-53 .

Canlı, Z, Canl, B. (2020). Distance education and young learners of English during curfew period due to coronavirus pandemic, International Journal of Social Sciences and Education Research, 6(2), 241251.

Çakın, M., Külekçi Akyavuz, E. (2020). The Covid-19 process and its reflection on education: An analysis on teachers' opinions. International Journal of Social Sciences and Education Research, 6(2), 165-186.

EBA. (2017). EBA hakkında. Retrived August 06, 2020, from. http://www.eba.gov.tr/

Elhaty, İ.A., Elhadary, T., Elgamil, R.A.M. and Kılıç, H. (2020). Teaching University Practical Courses Online during COVID-19 Crisis: A Challenge for ELearning, Journal of Critical Reviews, 7 (8), 2865-2873

Geçgel, H., Kana, F. ve Eren, D. (2020). Türkçe eğitiminde dijital yetkinlik kavramının farklı değişkenler açısından incelenmesi. Ana Dili Eğitimi Dergisi, 8(3), 886-904.

Huang, R.H., Liu, D.J., Tlili, A., Yang, J.F., Wang, H.H., et al. (2020). Handbook on Facilitating Flexible Learning During Educational Disruption: The Chinese Experience in Maintaining Undisrupted Learning in COVID-19 Outbreak. Beijing: Smart Learning Institute of Beijing Normal University.

Kesendere, Y., Şenol-Sakin, A., \& Acar, A.K. (2020). Educators' views on online/distance violin education at Covid-19 outbreak. Journal for the Interdisciplinary Art and Education, 1(1), 1-19.

Littlefield, J. (January 14, 2018). The Difference Between Synchronous and Asynchronous Distance Learning. Retrived August 06, 2020, from. https://www.thoughtco.com/synchronous-distancelearning-asynchronous-distancelearning-1097959

Miks, J., \&amp; J., Mcllwaine. (2020, April 20). Keeping the world's children learning through COVID-19. Retrieved September 06, 2020, from https://www.unicef.org/coronavirus/keeping-worldschildren-learning-through-covid-19

Milli Eğitim Bakanlığı, (2017). Eğitimde FATíH Projesi hakkında. Retrived August 06, 2020, from. http://fatihprojesi.meb.gov.tr/proje-hakkinda/

Millı̂ Eğitim Bakanlığı. (2020). Bakan Selçuk, koronavirüs'e karşı eğitim alanında alınan tedbirleri açıkladı. Retrived August 06, 2020, from. https://www.meb.gov.tr/bakan-selcuk-koronaviruse-karsiegitim-alaninda-alinan-tedbirleri-acikladi/haber/20497/tr

Pala, F, Arslan, H, \& Özdinç, F. (2017). Eğitim Bilişim Ağı web sitesinin otantik görevler ve göz izleme ile kullanılabilirliğinin incelenmesi. Ihlara Ĕgitim Araştırmaları Dergisi, 2(1), 24-38.

Sharma,N., and Sharma. K. (2020). Will Digital Education Take Over Conventional Education during Covid 19 Pandemic: Challenges \& Problems Faced by Teachers in Online Education. Journal of Critical Reviews, 7 (17), 878-892.

Singh, V., \& Thurman, A. (2019). How Many Ways Can We Define Online Learning? A Systematic Literature Review of Definitions of Online Learning (1988-2018). American Journal of Distance Education 33.4: 289- 306.

Sintema, E.J. (2020). Effect of Covid-19 on the Performance of Grade 12 Students: Implication for STEM Education, EURASIA Journal of Mathematics, Science and Technology Education, 16(7), em1851. 
Sreehari, P. (2020). Online Learning During The Covid-19 Lockdown: Learners' Perceptions. Journal of Critical Reviews, 7 (19), 300-307.

YÖK. (n.d.). Basın açıklaması Retrieved August 06, 2020, from https://www.yok.gov.tr/Sayfalar/Haberler/2020/YKS\%2520Ertelenmesi\%2520Bas\%C4\%B1n \%2520A\%C3\%A7\%C4\%B1klamas\%C4\%B1.aspx

Dersleri Platformu öğrencilerin erişimine açıldı. (n.d.). Retrieved August 04, 2020, from https://www.aa.com.tr/tr/egitim/yok-dersleri-platformu-ogrencilerin-erisimineacildi/1775922

YÖK. (n.d.). YÖK'ten üniversite öğrencileri için kayıt dondurma ve erteleme hakkı. Retrieved August 02, 2020, from https://www.yok.gov.tr/Sayfalar/Haberler/2020/erteleme-ve-kayit-dondurmahakki.aspx

Zhou, L., Li, F., Wu, S., \& Zhou, M. (2020). "School's Out, But Class's On”, The Largest Online Education in the World Today: Taking China's Practical Exploration During The COVID-19 Epidemic Prevention and Control as an Example. Best Evidence in Chinese Education, 4(2), 501-519. 